\title{
Altitudinal gradient in species richness and composition of dung beetles (Coleoptera: Scarabaeidae) in an eastern Euro-Mediterranean locality: Functional, seasonal and habitat influences
}

\author{
YAKUP ŞENYÜZ ${ }^{1}$, JORge M. LOBO ${ }^{2, *}$ and KeMAL DINDAR ${ }^{1}$ \\ ${ }^{1}$ Kütahya Dumlupinar University, Faculty of Art and Science, Department of Biology, Kütahya, Turkey; \\ e-mails: yakupsenyuz@gmail.com, kemaldindar@gmail.com \\ ${ }^{2}$ Dep. Biogeography and Global Change, Museo Nacional de Ciencias Naturales, CSIC. c/ José Gutiérrez Abascal 2, 28006, \\ Madrid, Spain; e-mail: Jorge.Lobo@mncn.csic.es
}

Key words. Coleoptera, Scarabaeidae, Scarabaeinae, Aphodiinae, dung beetles, species richness, historical factors, elevational turnover, seasonal variation, habitat, Anatolia

\begin{abstract}
The altitudinal gradient in diversity of dung beetles (Scarabaeidae) was studied in a Mediterranean mountain chain located in Central Anatolia to (i) determine if there are altitudinal differences between the main taxonomic groups, (ii) describe the seasonal variations in these assemblages and (iii) assess whether closed habitats influence dung beetle diversity differentially at different altitudes. Beetles were collected throughout a year at 14 localities between 469 and $1810 \mathrm{~m}$ above sea level in three different types of habitats. Dung beetle assemblages at 400 to $1200 \mathrm{~m}$ did not vary greatly in species richness, abundance and biomass. However, they varied in composition, with the assemblages dominated by species of Scarabaeinae up to $900 \mathrm{~m}$, whereas in the mid-mountain assemblages (from $900 \mathrm{~m}$ to $1600 \mathrm{~m}$ ) the numbers of species of Aphodiinae was higher. The decline with increase in altitude in richness, abundance and biomass of both small and large species of Scarabaeinae up to $1500 \mathrm{~m}$, together with the constancy of these parameters in the case of Aphodiinae, accounts for the changes in the composition from the lowland to mid-mountain localities. Unlike at other Mediterranean localities, the open/closed structure of the habitat only slightly influences these assemblages independently of altitude or season. The general seasonal pattern follows the classical Mediterranean bimodal pattern associated with summer drought, but the patterns are more complex when the seasonal responses of the different groups and at different localities are analysed separately. We propose that the interplay between local climatic conditions (mainly temperature) and evolutionary conserved species preferences accounts for both the current seasonal and altitudinal gradients and the changes in species composition in terms of Aphodiinae and Scarabaeinae.
\end{abstract}

\section{INTRODUCTION}

Altitudinal gradients in diversity and composition of ectothermic animals, such as insects, have been studied in different regions of the world (e.g., McCoy, 1990; Szewczyk \& McCain, 2016; Beck et al., 2017; Laiolo et al., 2018). With the help of these studies, it is possible to determine the effects of rapid changes in environmental conditions on assemblages and explore the probable causes of diversity patterns. Although mid-altitudinal peaks in species richness are frequently recorded, different trends whose root causes are always difficult to discern also occur. The main factors associated with altitudinal gradients in diversity are related to the following: (i) the biological effects of the decrease in temperature, energy or productivity with altitude (Brown et al., 2004); (ii) the role played by geometric or spatial constraints, such as the mid-domain effect (Colwell \& Lees, 2000) or the decrease in area with altitude
(Rosenzweig, 1995); (iii) the generally disturbed status of lowlands landscapes (McCoy, 1990); (iv) the juxtaposition of species groups with different climatic tolerances (Lomolino, 2001; Oommen \& Shanker, 2005); or even (v) the role played by contingent factors related to the idiosyncratic evolution of the involved groups and the composition of the regional pool of species (Ricklefts, 2006; Laiolo et al., 2018).

In the case of dung beetles, many studies have been conducted in South America (Nunes et al., 2016; da Silva et al., 2018; Espinoza \& Noriega, 2018), Africa (Davis et al., 1999; Mongyeh et al., 2018), South-East Asia (Hanski, 1983), Australia (Monteith, 1985) and Europe (Lumaret \& Stiernet, 1991, 1992; Martín-Piera et al., 1992; Menéndez \& Gutiérrez, 1996; Jay-Robert et al., 1997, 2008; RomeroAlcaraz \& Ávila, 2000; Lobo et al., 2007a, b; Menéndez et al., 2014; Chamberlain et al., 2015; Errouissi \& Jay-

\footnotetext{
* Corresponding author; e-mail: Jorge.Lobo@mncn.csic.es
} 
Robert, 2019). In Europe, most of these studies are limited to the westernmost area of the Mediterranean region. Both a more-or-less continuous decline in species richness and a mid-altitudinal peak can be found in these altitudinal gradients. The drastic decline in the species richness is often associated with the lack of distinctive dung beetle assemblages able to inhabit high-altitude environments (Jay-Robert et al., 1997); that is, high altitude assemblages are thus basically composed of a reduced number of species that also inhabit lower altitudes. In contrast, when two main assemblages representing highland and lowland species groups are present, the altitudinal decline in species richness can be less obvious, may disappear or be transformed into a mid-altitudinal peak (Lumaret \& Stiernet, 1994; Jay-Robert et al., 1997; Lobo et al., 2007a, b), with the maximum richness associated with the occurrence of species belonging to both of the two altitudinal assemblages. In South America, highland open biomes seem to be inhabited by a low number of distinctive species typically belonging to the same higher taxonomic ranks as those inhabiting lowland localities (Escobar et al., 2006; da Silva et al., 2018). However, in the western Palearctic (Jay-Robert et al., 1997) and at the border of the Nearctic and Neotropical realms (Lobo \& Halffter, 2000), highland assemblages basically consist of species with a different evolutionary history and origin from those occupying lowlands (the so-called horizontal colonization according to Lobo \& Halffter, 2000). Thus, in these regions, the occurrence of distinct phylogenetic groups differing in origin and eco-physiological adaptions involves the three main groups of Scarabaeoidea dung beetles: Geotrupidae, Aphodiinae and Scarabaeinae.

The tendency for high-level groups to maintain their environmental preferences over evolutionary time (niche conservatism; Wiens \& Graham, 2005) can be key to understanding the differences in the altitudinal distributions of Geotrupidae/Aphodiinae and Scarabaeinae (Lobo, 1997). Geotrupidae and Aphodiinae are the dominant groups at high altitudes and latitudes due to their general cold-temperate eco-physiological adaptations (Hanski, 1980; Lumaret \& Stiernet, 1994; Lobo, 2000), whereas Scarabaeinae prevail in lowlands and at Mediterranean localities (Lumaret \& Stiernet, 1992; Martín-Piera et al., 1992; Jay-Robert et al., 1997; Lobo et al., 2007b). The post-glacial colonization of highlands and latitudes north of the Alps (approximately $47^{\circ} \mathrm{N}$ ) by species well adapted to cold temperate conditions resulted in the species richness and compositional gradient of dung beetles in Europe (Hortal et al., 2011). Some mountain chains could be acting not only as barriers, hindering the colonization of northern environments after the ice retreated but also may serve as a refuge for some species currently considered to be mountain endemics. As a consequence, the northernmost mountain chains at the boundary of the glaciated territory (the Alps) have today a high number of high-altitude species, with restricted distributions (endemics) and, consequently, a flatter relationship between species richness and altitude (Errouissi \& Jay-Robert, 2019). In contrast, the number of narrowly distributed species decreases and the altitudinal decline in species richness increases in the mountains away from glaciated Pleistocene regions such as Sierra Nevada on the Iberian Peninsula (Jay-Robert et al., 1997).

In view of the above, this study aims to examine the altitudinal gradient in dung beetle diversity in a mountain chain with a warm summer Mediterranean climate but located in the easternmost part of the Mediterranean area (Central Anatolia, Turkey). The main aim is to ascertain whether the altitudinal pattern in a mountain chain located at the crossroads of Asia, Europe and Africa is similar to that in European regions considered as Pleistocene refuges. In this study, we assume that the change in the required thermal energy associated with the differing evolutionary eco-physiological preferences of taxonomic groups of high rank are the main drivers conditioning dung beetle altitudinal patterns. As Geotrupidae species do not seem to be present in this region, altitudinal patterns will be separately analysed for three groups of species (Aphodiinae, small Scarabaeinae and large Scarabaeinae species) to determine if their altitudinal patterns differ. Similarly, altitudinal gradients will be compared between seasons and localities differing in the structure of their vegetation. Under Mediterranean conditions, a bimodal seasonal pattern in species diversity is the rule (Lumaret \& Kirk, 1991), and the number of dung beetle species that can be collected diminished in forest or scrubland vegetation structure (Lumaret \& Kirk, 1987; Numa et al., 2012; Errouissi \& JayRobert, 2019). Thus, assuming that altitudinal gradients in dung beetles must be mainly explained by climatic factors (Birkett et al., 2018), we hypothesize that these gradients should vary during the course of a year and that closed habitats may be acting as "thermal shelters" during the hottest and driest conditions, thus influencing dung beetle assemblages differently at different altitudes.

\section{MATERIALS AND METHODS}

\section{Study area}

The altitudinal transect was carried out in the Kütahya Province located in the western Anatolian part of the Aegean Region of Turkey (between $38^{\circ} 70^{\prime}-39^{\circ} 80^{\prime} \mathrm{N}$ and $29^{\circ} 00^{\prime}-30^{\circ} 30^{\prime} \mathrm{E}$ ). Among the three major biogeographical regions recognized in Turkey (Irano-Turanian, European-Siberian and Mediterranean), the first two are present at Kütahya (Davis, 1965; Akman, 1995). The climate in the area studied is Mediterranean, with an annual rainfall approximately $601.8 \mathrm{~mm}$ and mean annual temperature of $11.8^{\circ} \mathrm{C}$ (from $23.3^{\circ} \mathrm{C}$ in July to $0.9^{\circ} \mathrm{C}$ in January) (Akman, 1999). Snow is present in the region for about 25-40 days each year.

\section{Data sampling}

Dung beetles (Scarabaeidae: Scarabaeinae and Aphodiinae) were collected at 14 different localities at altitudes ranging from 469 to $1810 \mathrm{~m}$ a.s.l. within an area of approximately $1500 \mathrm{~km}^{2}$ (Fig. 1). The mean distance between neighbouring localities is $6.2 \mathrm{~km}$, ranging from $0.8 \mathrm{~km}$ between the two localities located at the highest altitudes, to $28.3 \mathrm{~km}$ between localities at 893 and 988 $\mathrm{m}$ a.s.l. At all the localities there was an abundance of livestock consisting mainly of cattle and sheep. Large wild mammals, such as wolves, deer, wild boar, roe deer and hares are also common at all the localities studied. From June 2010 to May 2011, three baited pitfall traps (Veiga et al., 1989) were placed at each locality; 


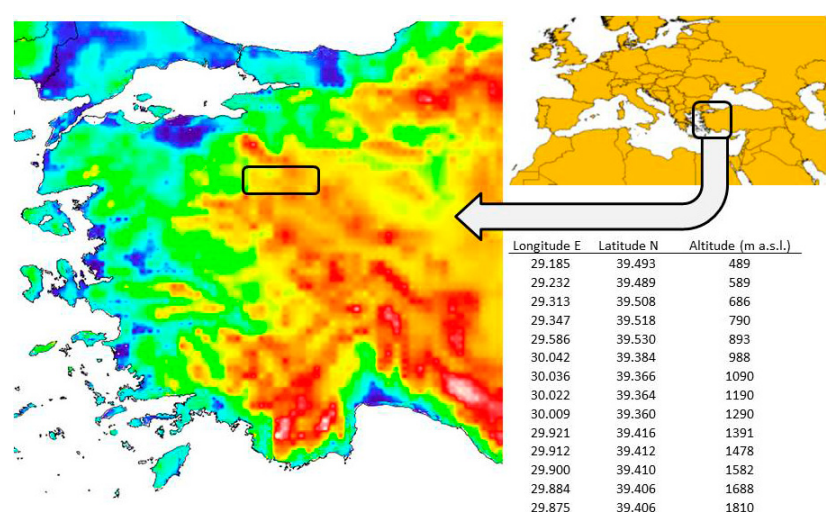

Fig. 1. Map showing the location of the region studied (black rectangles) and the latitudes, longitudes and altitudes of the localities sampled. Colour gradient on the map represents altitudes from lowlands (blue) to high mountains (red/white).

one trap inside forest (closed habitat), another in a pasture (open habitat), and the third in a forest-pasture ecotone site (mixed habi- tat). The forest vegetation at the low altitude locality is a riparian forest of ash trees, while pines, Pinus nigra subsp. pallasiana (Lamb.), are the dominant trees at the localities between 589 and $790 \mathrm{~m}$ a.s.l. and Quercus spp in the forest located at $893 \mathrm{~m}$. Juniper trees dominate the forest between 988 and $1290 \mathrm{~m}$ a.s.1. while the remaining localities at the highest altitudes were in mixed forest of species of Juniperus, Cedrus, Pinus and Quercus. All the baited traps were set $50 \mathrm{~m}$ apart. Baited pitfall traps consisted of plastic containers $(20 \mathrm{~cm}$ depth $\times 25 \mathrm{~cm}$ diameter) buried up to their rims in the soil; these containers contained water with a few drops of soap and formaldehyde to reduce surface tension and preserve the specimens. Fresh cattle dung $(\approx 1000 \mathrm{~g})$ was used to bait each trap, which was placed on a wire grid above the buried container. All the pitfall traps were set in the field for $72 \mathrm{~h}$. A total of 504 pitfall traps (SUs) were set ( 1 pitfall trap $\times 3$ habitats $\times 14$ altitudes $\times 12$ months). Collected specimens were deposited in the entomology museum of the Biology Department at Dumlupinar University.

\section{Statistical treatment}

Trap data was used to determine the general variation in species richness, total abundance and total biomass in relation to the three factors considered as representative of gradients in al-

Table 1. Relationships between altitude and species richness ( $\mathrm{S}$ ), abundance ( $\mathrm{N}$; in log) and biomass (B; in log) for the total obtained data as well as for the samples obtained in open, closed or mixed habitats according to the vegetation cover of each sampling site. Relationships for the three considered functional/taxonomic groups $(G)$ are specifically examined. All these relationships were adjusted to linear and quadratic functions in order to consider possible curvilinear relationships. A quadratic function is considered statistically significant when both linear and quadratic terms have a significance level $\leq 1 \%$ (in bold). Regression coefficients for linear (B) and quadratic (Bc) terms were included ( \pm S.D.) and also Pearson correlation coefficients $(r)$.

\begin{tabular}{|c|c|c|c|c|c|c|c|c|c|c|c|}
\hline Habitat & Variable & G & Relationship & $\mathrm{B}$ & $\mathrm{t}$ & $\mathrm{P}$ & $\mathrm{BC}$ & $\mathrm{t}$ & $\mathrm{P}$ & $\mathrm{r}$ & $P$ \\
\hline \multirow{9}{*}{$\begin{array}{l}\frac{\pi}{0} \\
\stackrel{0}{0}\end{array}$} & \multirow{3}{*}{ S } & Aphodiinae & curvilinear +/- & $2.54 \pm 1.09$ & 2.33 & 0.04 & $-0.01 \pm 0.001$ & -2.98 & 0.01 & -0.66 & 0.01 \\
\hline & & nall Scarabaeinae & linear - & $-0.68 \pm 0.22$ & -3.09 & 0.009 & & & & -0.66 & 0.009 \\
\hline & & rge Scarab & curvilit & $6 \pm 0.70$ & -3.37 & 0.006 & $0.01 \pm 0.001$ & 2.74 & 0.02 & -0.70 & 0.005 \\
\hline & \multirow{3}{*}{$\mathrm{N}$} & Aphodiinae & curvilinear $+/-$ & $0.85 \pm 0.27$ & 3.11 & 0.01 & $-0.00 \pm 0.00$ & -3.85 & 0.002 & -0.66 & 0.01 \\
\hline & & hall Scarabaeinae & linear - & $-0.09 \pm 0.05$ & -1.72 & 0.11 & & & & -0.44 & 0.11 \\
\hline & & Large Scara & curvilir & -1.2 & -2.81 & 0.02 & $0.00 \pm 0.00$ & 2.42 & 0.03 & -0.54 & 0.04 \\
\hline & \multirow{3}{*}{$B$} & Aphodiin & curvilin & $0.83 \pm 0.28$ & 2.98 & 0.01 & $-0.00 \pm 0.00$ & -3.74 & 0.003 & -0.67 & 0.009 \\
\hline & & lall Scarabc & linear - & $-0.08 \pm 0.04$ & -1.80 & 0.09 & & & & -0.46 & 0.1 \\
\hline & & Large Scar & & -0 & -2.73 & 0.02 & & & & -0.62 & 0.02 \\
\hline \multirow{9}{*}{ Оั } & \multirow{3}{*}{$\mathrm{s}$} & Aphodiin & curvilinear $+/-$ & $2.97 \pm 1.29$ & 2.30 & 0.04 & $-0.001 \pm 0.00$ & -2.71 & 0.02 & -0.48 & 0.08 \\
\hline & & Small Scaraba & linear - & $-0.85 \pm 0.31$ & -2.72 & 0.02 & & & & -0.62 & 0.02 \\
\hline & & Large Scarab & curvilin & -2.1 & -3.87 & 0.002 & $0.001 \pm 0.00$ & 3.19 & 0.009 & -0.71 & 0.005 \\
\hline & \multirow{3}{*}{$\mathrm{N}$} & Aphodiinae & curvilinear $+/-$ & $0.97 \pm 0.28$ & 3.42 & 0.006 & $-0.00 \pm 0.00$ & -4.25 & 0.001 & -0.67 & 0.009 \\
\hline & & Small Scarabaeinae & linear - & $-0.10 \pm 0.06$ & -1.75 & 0.1 & & & & -0.45 & 0.10 \\
\hline & & Large Scarab & curvilin & $-1.23 \pm 0.38$ & -3.21 & 0.008 & $0.00 \pm 0.00$ & 2.74 & 0.02 & -0.59 & 0.03 \\
\hline & \multirow{3}{*}{ B } & Aphodiinae & curvilinear $+/-$ & $1.07 \pm 0.31$ & 3.49 & 0.005 & $-0.001 \pm 0.00$ & -4.32 & 0.001 & -0.67 & 0.009 \\
\hline & & Small Scarabaeinae & linear - & $-0.09 \pm 0.05$ & -1.79 & 0.1 & & & & -0.46 & 0.1 \\
\hline & & Large Scarabaeinae & line & $-0.20 \pm 0.06$ & -3.25 & 0.01 & & & & -0.68 & 0.007 \\
\hline \multirow{9}{*}{ 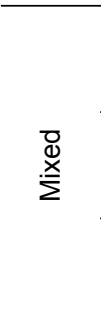 } & \multirow{3}{*}{ S } & Aphodiinae & curvilinear $+/-$ & $2.11 \pm 0.72$ & 2.94 & 0.01 & $-0.001 \pm 0.00$ & -3.86 & 0.003 & -0.74 & 0.03 \\
\hline & & Small Scarabaeinae & linear - & $-0.75 \pm 0.14$ & -5.30 & 0.0002 & & & & -0.84 & $<0.0001$ \\
\hline & & Large Scarabaeinae & curvilinear -/+ & $-2.16 \pm 0.62$ & -3.51 & 0.005 & $-0.001 \pm 0.00$ & 2.94 & 0.01 & -0.65 & 0.01 \\
\hline & \multirow{3}{*}{$\mathrm{N}$} & Aphodiinae & curvilinear +/- & $1.03 \pm 0.33$ & 3.16 & 0.009 & $-0.00 \pm 0.00$ & -3.84 & 0.003 & -0.62 & 0.02 \\
\hline & & Small Scarabaeinae & linear - & $-0.09 \pm 0.05$ & -1.86 & 0.09 & & & & -0.47 & 0.09 \\
\hline & & Large Scarabaeinae & linear - & $-0.17 \pm 0.10$ & -1.68 & 0.12 & & & & -0.44 & 0.12 \\
\hline & \multirow{3}{*}{ B } & Aphodiinae & curvilinear $+/-$ & $1.06 \pm 0.35$ & 3.05 & 0.01 & $-0.001 \pm 0.00$ & -3.76 & 0.003 & -0.64 & 0.01 \\
\hline & & Small Scarabaeinae & linear - & $-0.09 \pm 0.04$ & -1.91 & 0.08 & & & & -0.48 & 0.08 \\
\hline & & Large Scarabaeinae & linear - & $-0.29 \pm 0.23$ & -1.26 & 0.23 & & & & -0.34 & 0.23 \\
\hline \multirow{9}{*}{$\begin{array}{l}\bar{D} \\
\mathscr{0} \\
\text { O }\end{array}$} & \multirow{3}{*}{$\mathrm{S}$} & Aphodiinae & curvilinear +/- & $2.67 \pm 1.14$ & 2.35 & 0.04 & $-0.001 \pm 0.00$ & -2.77 & 0.02 & -0.49 & 0.07 \\
\hline & & Small Scarabaeinae & linear - & $-0.20 \pm 0.31$ & -0.65 & 0.52 & & & & -0.18 & 0.53 \\
\hline & & Large Scarabaeinae & linear - & $-0.12 \pm 0.10$ & -1.22 & 0.24 & & & & -0.33 & 0.25 \\
\hline & \multirow{3}{*}{$\mathrm{N}$} & Aphodiinae & linear - & $-0.15 \pm 0.06$ & -2.58 & 0.02 & & & & -0.57 & 0.02 \\
\hline & & Small Scarabaeinae & linear - & $-0.06 \pm 0.07$ & -0.87 & 0.40 & & & & 0.24 & 0.40 \\
\hline & & Large Scarabaeinae & linear - & $-0.06 \pm 0.09$ & -0.69 & 0.50 & & & & -0.19 & 0.50 \\
\hline & \multirow{3}{*}{ B } & Aphodiinae & linear - & $-0.15 \pm 0.05$ & -2.64 & 0.02 & & & & -0.61 & 0.02 \\
\hline & & Small Scarabaeinae & linear - & $-0.05 \pm 0.06$ & -0.87 & 0.40 & & & & -0.24 & 0.40 \\
\hline & & Large Scarabaeinae & linear - & $-0.11 \pm 0.11$ & -1.00 & 0.34 & & & & -0.28 & 0.34 \\
\hline
\end{tabular}


titude (sites; 14 levels), season (months; 12 levels) and vegetation cover (habitats; 3 levels). The fresh biomass of each species was estimated using the length-to-body weight relationship for dung beetles (Lobo, 1993; $r=0.989, \mathrm{p}<0.001$ ). Body length was obtained from the literature (Baraud, 1977) and original descriptions of the species. The final slope of the species accumulation curve with the addition of individuals (coverage) was estimated as a measure of survey completeness for each of the sites sampled (altitude) using the function "iNEXT" in the "iNEXT" R package (Hsieh et al., 2016). Variation in assemblages was also analysed for the three groups of species: Aphodiinae, small Scarabaeinae and large Scarabaeinae species. Aphodiinae species are of small size living and feeding usually inside relatively fresh dung (endocoprids). Most Scarabaeinae and Geotrupidae species are paracoprids (tunnelers) or telecoprids (rollers), digging vertical tunnels below the dung pat and carrying dung into the bottom of the burrow, or rolling and burying portions of dung away from dung pats. We discriminate small from large species as those below and above $1 \mathrm{~cm}$ in length.

The relationships between altitude (A) and species richness, abundance or biomass were adjusted to quadratic functions (A $+\mathrm{A}^{2}$ ) when required in order to consider possible curvilinear relationships. A quadratic function is considered statistically significant when both linear and quadratic terms are significant at $\leq 1 \%$. In addition, simple two-variable scatterplots and threedimensional contour plots using the Wafer fit method were also used to explore the variations in species richness, abundance and biomass along altitude, seasonal and habitat gradients. Wafer fit method displays surface data using raw data by constructing triangles between the individual points and then plotting these triangles using standard surface plot techniques. All these analyses were performed using StatSoft's software STATISTICA v10.0.

A rectangular matrix containing the abundances of each species in SUs (504 SUs $\times 92$ species; see Supplementary Table S1) was converted into a triangular similarity matrix reflecting the distance in composition between assemblages. Abundance data was previously transformed logarithmically using $\log (\mathrm{x}+1)$. The recommended Hellinger index (Legendre \& Gallagher, 2001) was used for this purpose, with a dummy species with a value of 1 being added prior to computing the similarities to force samples with few individuals to have some similarity (Clarke \& Gorley, 2015). A non-metric Multi-Dimensional Scaling (nMDS) was used to represent compositional differences. Subsequently, an analysis of similarity (ANOSIM) without replication was carried on the obtained resemblance matrix in a three-way crossed design $(\mathrm{A} \times \mathrm{M} \times \mathrm{H}$; A was an ordered factor representing altitude sites, $\mathrm{M}$ months and $\mathrm{H}$ habitats). ANOSIM is a non-parametric technique that does not require the fulfilment of multivariate normality assumptions and in which significance levels are established by means of a permutation test (999 permutations) (Clark \& Green, 1988). Thus, ANOSIM was used to test the null hypothesis that there were no compositional differences in the assemblages between the levels of the three factors. An $R$ value generally between 0 to 1 was used to measure the ratio of average rank similarities within and between the levels of the considered factors (i.e., the global test for altitude average the comparisons of the assemblages recorded at different altitudes in the same month and habitat).

\section{RESULTS}

\section{General altitudinal patterns}

A total of 41,131 individuals belonging to 92 species were collected. Sample coverage of site inventories ranges between 0.975 and 0.999 (mean $\pm 95 \%$ confidence inter-
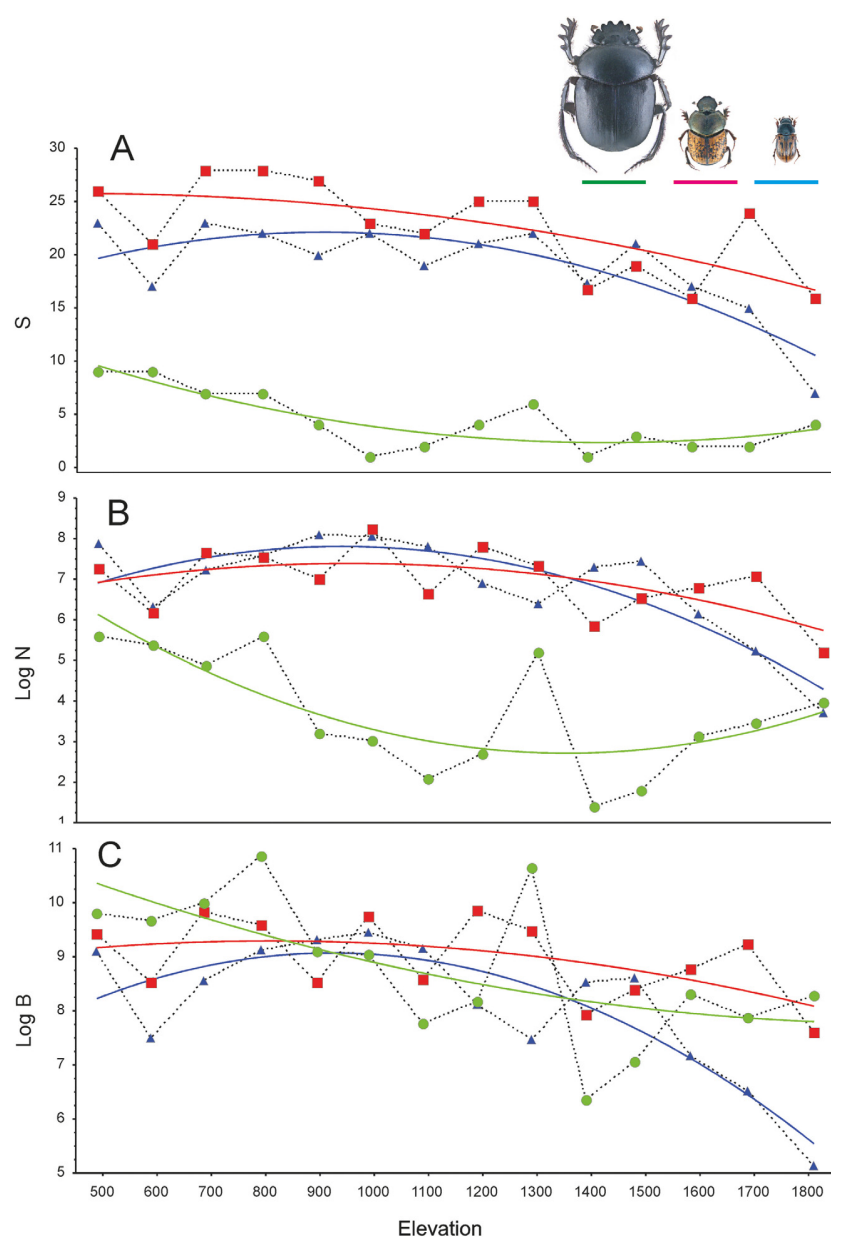

Fig. 2. Altitudinal variation in the total number of species collected $(A)$, individuals collected (B) and the biomass (C) of the three taxonomic groups studied. Green circles represent the values for large species of Scarabaeinae, blue triangles small species of Aphodiinae and red squares small species of Scarabaeinae. Continuous lines represent the curvilinear relationships of the data (quadratic functions).

val; $0.995 \pm 0.003$ ), so few species remained undetected at each site, and the pattern in general species richness can be considered reliable. The correlation between observed and predicted species richness values obtained at the same sample coverage $(0.98)$ was positive and statistically significant $(r=0.751 ; \mathrm{p}=0.002)$.

Mean species richness per site was $46.0 \pm 5.4$ (mean $\pm 95 \%$ confidence interval). Total species richness decreased with altitude at a rate of 1.8 species per $100 \mathrm{~m}(r=$ $-0.81, \mathrm{p}<0.001)$. Total species richness remained almost unchanged up to $1200 \mathrm{~m}$ (approximately 51 species) and then decreased to 27 species at the highest altitude. This decreasing pattern differs in the three groups considered (Table 1; Fig. 2A). Aphodiinae species showed a curvilinear relationship in which the species remain almost constant up to $1500 \mathrm{~m}$ and then decreased. The species richness variation in large species of Scarabaeinae is also curvilinear but reversed; the number of species decreased up to $1400-1500 \mathrm{~m}$ and then remained constant or increased slightly (Fig. 2A). The species richness of small Scarabaeinae species decreased linearly with altitude (0.68 species per $100 \mathrm{~m})$. Mean abundance per site was $2938 \pm 1008$ 
individuals. Total abundance also decreased with altitude (243 individuals per $100 \mathrm{~m}$ ) following a very similar pattern (Table 1; Fig. 2B). Mean biomass per site was $28.4 \pm$ 11.8 grams and total biomass decreased with altitude $(2.9 \mathrm{~g}$ per $100 \mathrm{~m}$ ) until reaching $6.1 \mathrm{~g}$ at the highest altitude. Total biomass of the Aphodiinae species decreased even more with increasing altitude again following a curvilinear pattern (Fig. 2C). The biomass of small and large species of Scarabaeinae linearly diminished with altitude but at rates that are not statistically significant $(\mathrm{P}>0.01$; see Table 1$)$.

\section{Altitudinal patterns between habitats}

In closed and mixed habitats there were similar total numbers of species (77 and 78 species, respectively), while species richness in open habitats was slightly higher (83 species). However, total abundance and biomass seems to be higher in open (15,928 individuals; $160.1 \mathrm{~g})$ and closed habitats $(14,374$ individuals; $134.0 \mathrm{~g})$ than in mixed habitats $(10,829$ individuals; $104.3 \mathrm{~g})$. The number of species of Aphodiinae (from 34 to 36) and small Scarabaeinae (from 33 to 35 ) was similar in the three habitats, while the number of large species of Scarabaeinae was only slightly lower in mixed habitats ( 9 species) than in open or closed habitats (12 and 11 species, respectively).

Altitudinal patterns follow similar decreasing tendencies when the data for each of the three habitats are examined individually. The linear decrease in species richness with altitude was similar in open $(1.74$ species per $100 \mathrm{~m} ; t=$ $-3.33, \mathrm{P}=0.006)$ and mixed habitats $(1.75$ species per 100 $\mathrm{m} ; t=-6.10, \mathrm{P}<0.0001)$. However, this decrease was low or even non-existent in closed habitats $(0.76$ species per $100 \mathrm{~m} ; t=-1.57, \mathrm{P}=0.14)($ Fig $3 \mathrm{~A})$. Abundance decreased similarly with altitude in open (102 individuals per $100 \mathrm{~m}$; $t=-3.01, \mathrm{P}=0.01)$, closed (60 individuals per $100 \mathrm{~m} ; t=$ $-2.07, \mathrm{P}=0.06)$ and mixed habitats ( 81 individuals per 100 $\mathrm{m} ; t=-2.85, \mathrm{P}=0.01$ ) (Fig. 3B). In the case of biomass, the altitudinal decrease was significant in both open $(1.34$ gr per $100 \mathrm{~m} ; t=-4.31, \mathrm{P}=0.0001)$ and mixed habitats (0.88 gr per $100 \mathrm{~m} ; t=-3.58, \mathrm{P}=0.004)$, but not in the closed habitat (0.65 gr per $100 \mathrm{~m} ; t=-1.57, \mathrm{P}=0.14)$ (Fig. 3C).

General altitudinal patterns for the three habitats hardly differed for the three groups (Table 1). The species richness, abundance and biomass of species of Aphodiinae in the three habitats decreased similarly at the highest sites; curvilinear (+/-) relationships in which the dependent variable first increased and then decreased with altitude. The species richness of small species of Scarabaeinae only clearly decreased with altitude in mixed habitats while the altitudinal patterns in richness, abundance and biomass hardly diminished independently of the habitat. Finally, large species of Scarabaeinae slightly increased in richness and abundance in the open habitats located at the highest altitudes but their abundance and biomass seemed to remain constant in mixed and closed habitats (Table 1).

\section{Seasonal variation}

Seasonal variation in total species richness followed the classic bimodal pattern in which the maximum number of
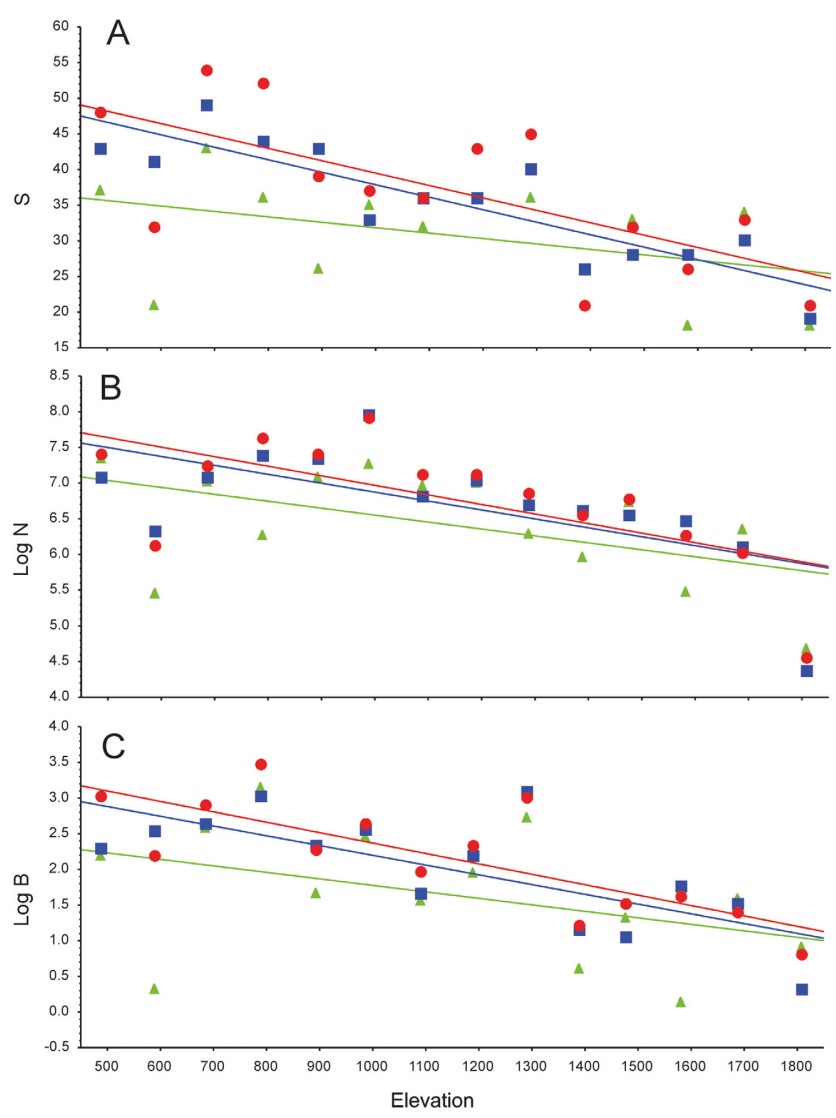

Fig. 3. Altitudinal variation in the number of species collected (A), individuals collected $(B)$ and the biomass $(C)$ recorded in the three habitats studied that differed in their vegetation cover. Red circles represent open pastures, green triangles closed habitats (forest) and blue squares mixed habitats. Continuous lines represent linear relationships of the data.

species was recorded in spring (May), and after the summer drought, a new increase in species richness was recorded in autumn (October; Fig. 4A). This bimodal pattern became partly blurred when total abundance (Fig. 4B) was considered. There was a third peak in biomass at the start of the summer (Fig. 4C). Interestingly, these two seasonal peaks were similar and clearly evident in the case of species of Aphodiinae, but much less obvious in the case of small species of Scarabaeinae (Fig. 4), in which the decline in abundance and biomass during summer was significantly less pronounced. For example, the number of these species collected in May and July were 31 and 24 (18 and 8 in the case of Aphodiinae). The seasonal pattern in the species of large Scarabaeinae was clearly unimodal peaking at the end of spring and in early summer (Fig. 4).

Considering collectively altitude, habitat and seasonal variations revealed that the bimodal seasonal pattern in species richness, abundance and biomass occurred in the three habitats studied (Fig. 5). The spring peak in species richness was followed by a species-poor summer period and a lower autumn peak. The spring peak was recorded at both the lowland (500-600 m) and mid-mountain localities (1100-1300 m) (Fig. 5). This pattern is similar in the three habitats, although there does not seem to be a peak in the lowlands in closed habitats. The abundance and biomass 

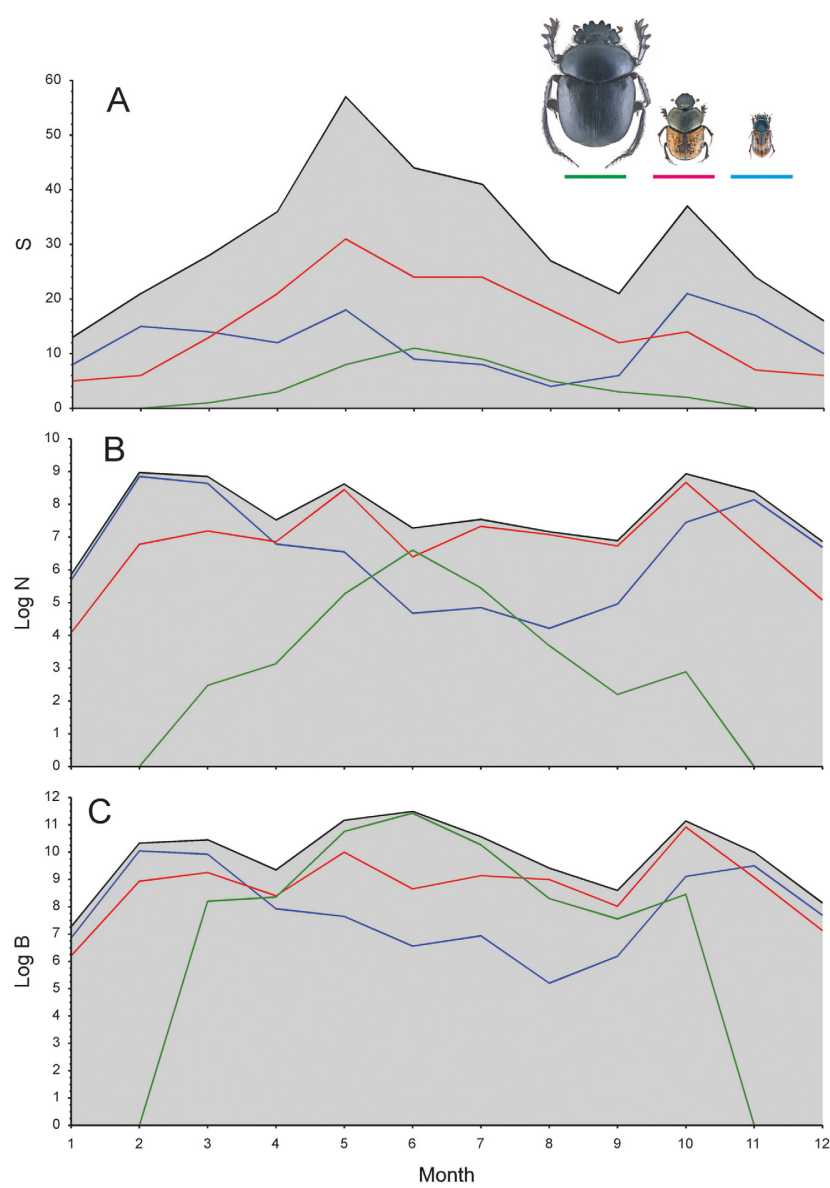

Fig. 4. Monthly variation from January (1) to December (12) in the number of species collected (A), individuals collected (B) and the biomass $(\mathrm{C})$. Total values are represented by the grey area, while green, blue and red lines represent the values for large species of Scarabaeinae, species of Aphodiinae and small species of Scarabaeinae, respectively.

values also show a bimodal seasonal pattern that it is less pronounced in the open and mixed habitats located in lowlands (Fig. 5).

\section{Assemblage composition}

ANOSIM $R$ values were $0.515(\mathrm{P}=0.001), 0.458(\mathrm{P}=$ $0.001)$ and $0.082(\mathrm{P}=0.01)$ for altitude, month and habitat, respectively. Thus, there was greater difference in composition associated with altitude and season than with habitat. nMDS ordination (Fig. 6A) revealed three main groups according to their dung beetle composition at different altitudes, and this approach was complemented by a completelinkage Cluster Analysis (not shown). At lowland sites $(\approx 400-800 \mathrm{~m}) 80.4 \%(\mathrm{n}=74)$ of all the species (92 species) were collected, and a few species exclusive to or more abundant at these sites were collected in comparatively low numbers (Fig. 6B). Only some species, such as Amidorus cribrarius ( $\mathrm{n}=781$ individuals; $5.79 \%$ of total), Onthophagus illyricus $(0.77 \%)$, O. taurus $(0.47 \%)$, Euonthophagus gibbosus (0.16\%), Caccobius mundus (0.20\%), Gymnopleurus mopsus $(0.52 \%)$, G. sturmi $(0.12 \%)$, Cheironitis furcifer $(0.43 \%)$ and Copris hispanus $(0.35 \%)$, can be considered as typical of lowland sites. The latter four species are large roller or tunnelling species of Scarabaeinae,
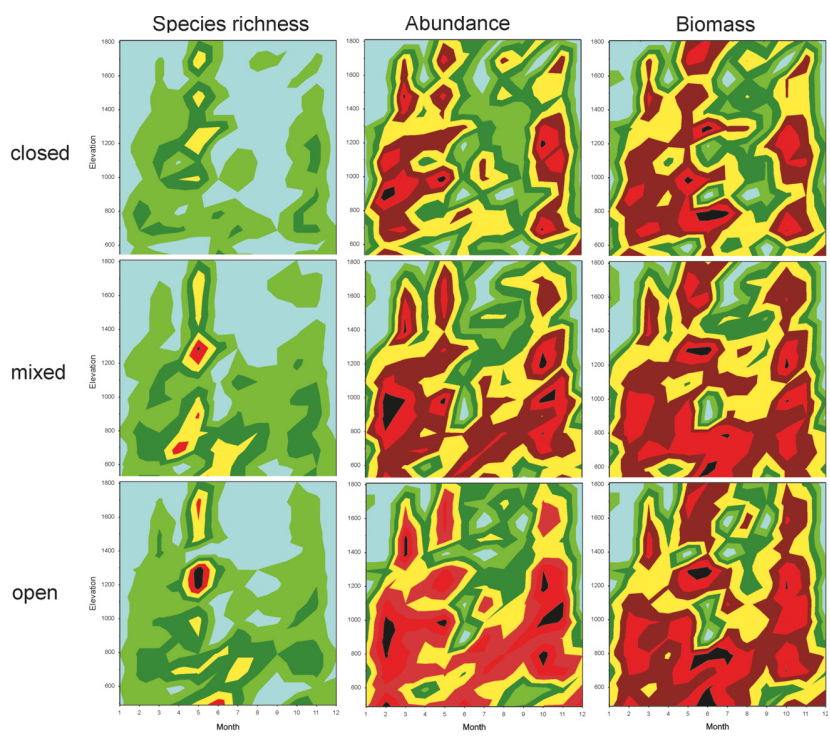

Fig. 5. Three-dimensional contour plots using the Wafer fit method to visualize the variations in species richness, abundance and biomass along altitudinal, seasonal and habitat gradients. Low values are represented by light green colour and high values by red/black colour.

and 11 of the 12 large species of Scarabaeinae occurred in the lowlands. At mid-mountain sites $(\approx 900-1700 \mathrm{~m})$ $84.8 \%$ of all the species $(\mathrm{n}=78)$ were collected and all those not collected $(92-78=14)$ were collected in the lowlands (Fig. 6B). Nimbus johnsoni (1.61\% of total), N. obliteratus $(1.43 \%)$, Euheptaulacus sus $(0.31 \%)$, Plagiogonus syriacus $(0.12 \%)$, Esymus alkani $(0.11 \%)$, Phalacronotus fumigatulus $(0.11 \%)$, Onthophagus suermelii $(0.11 \%)$ and Trichonotulus scrofa $(0.10 \%)$ can be considered to be typical species of mid-mountain sites, as all, except for one, are species of Aphodiinae. Finally, only 27 species (29.3\%) were collected at the highest site $(\approx 1800 \mathrm{~m})$, and none of them were recorded only at this altitude. Only Onthophagus gibbulus $(13.21 \%)$ could be classified as a species with a preference for habitats at this altitude (Fig. 6B).

\section{DISCUSSION}

The results clearly show that an increase in altitude is associated with a decrease in species richness, abundance and biomass of assemblages of dung beetles with no evidence of a mid-altitudinal peak. The altitudinal gradient in dung beetles at the eastern Euro-Mediterranean locality studied appears to be mid-way between what is recorded in south-western Mediterranean mountain ranges and in northernmost mountain chains at the boundary of the Pleistocene glaciated territory (the Alps). Those recorded in the former are characterized by a drastic decline in the species richness, which is associated with the lack of a distinctive high-altitude dung beetle assemblage. In contrast, there is a low or even non-existent decline in species richness recorded in the northernmost mountain chains, which is associated with the regional co-occurrence of assemblages of both highland and lowland species with different evolutionary histories (Jay-Robert et al., 1997; Lobo \& Halffter, 2000). 

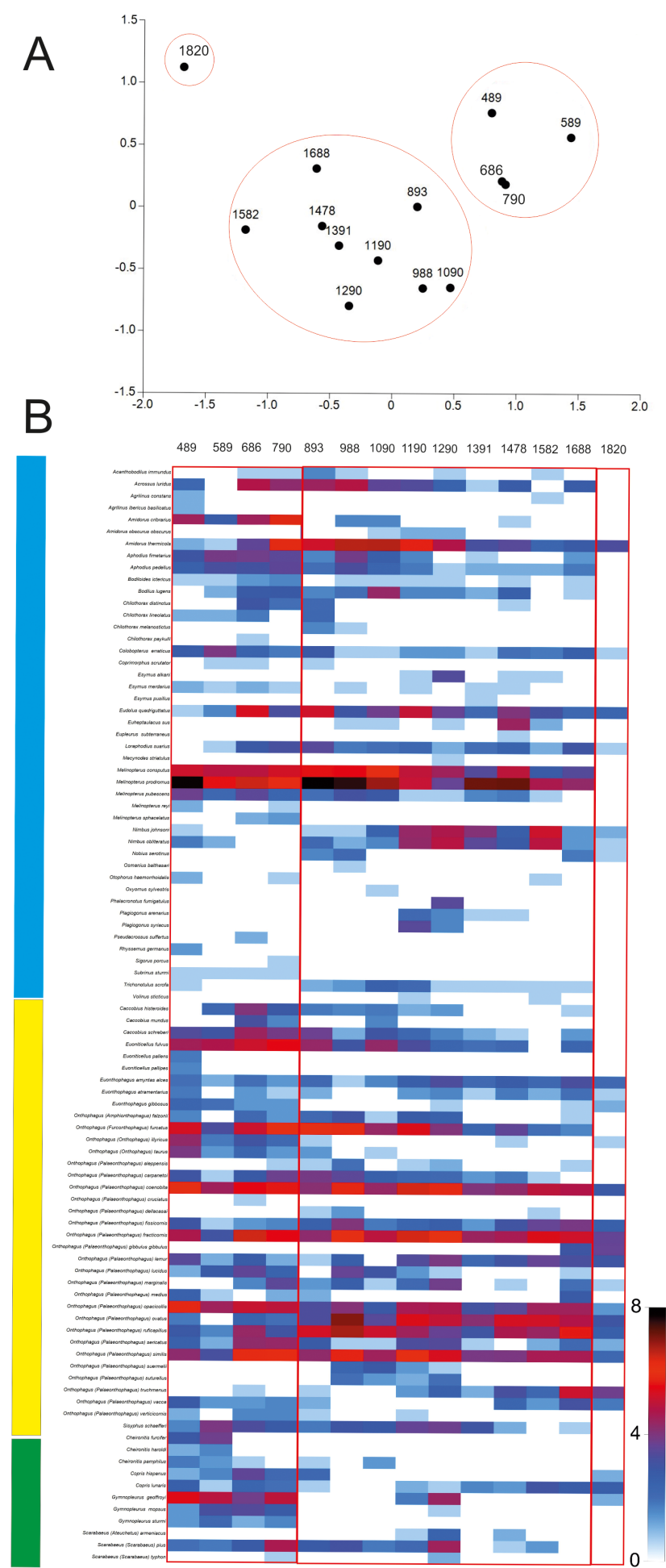

Fig. 6. (A) Results of the nMDS ordination (stress value $=0.07$ ), which represents the main groups of sites at different altitudes (from $489 \mathrm{~m}$ to $1810 \mathrm{~m}$ ) in terms of the composition of the assemblages of the dung beetles recorded there; these are also indicated by red circles, which are based on a complete-linkage Cluster Analysis. (B) Variation in the number of individuals of each species (in $\log x+1$ ) collected at each of the sites sampled at the different altitudes (see the colour scale on the right of the figure). Red squares delimit each of the three groups of sites revealed by the nMDS ordination and the multi coloured column on the left represents the proportion that were dweller species of Aphodiinae (blue), small-tunneling or rolling species of Scarabaeinae (yellow), or large-tunneling or rolling species of Scarabaeinae (green), respectively.
The decrease in species richness, abundance and biomass is also not uniform along the entire altitudinal range studied. Dung beetle assemblages at from 400 to $1200 \mathrm{~m}$ did not vary greatly in species richness, abundance and biomass, but they varied in composition, with the assemblages dominated by species of Scarabaeinae (large and small rolling and tunnelling species) up to $900 \mathrm{~m}$, whereas there were relatively more species of Aphodiinae (dwellers) in the mid-mountain assemblages (from $900 \mathrm{~m}$ to 1600 $\mathrm{m}$, approximately). Indeed, Aphodiinae species richness, abundance and principally biomass, only began to decrease above $1500 \mathrm{~m}$. Thus, the altitudinal decline up to $1500 \mathrm{~m}$ in richness, abundance and biomass of both small and large species of Scarabaeinae together with the relative constancy of these parameters in the case of Aphodiinae accounts for the compositional changes in the assemblages recorded with increasing altitude. The dung beetles recorded in the assemblages collected at the highest locality lack exclusive species (except maybe Onthophagus gibbulus), so with increase in altitude there is a general loss of species and not a change in the fauna. In contrast, the assemblages along the altitudinal gradient from lowlands $(400-800 \mathrm{~m})$ to mid-mountain areas (900-1600 m) basically imply a major taxonomic and functional change. This change is similar to that recorded in other European mountains (Jay-Robert et al., 1997; Lobo et al., 2007a) in which Aphodiinae and Geotrupidae dominate the assemblages at high altitudes, whereas Scarabaeinae are the dominant group in lowlands. Notably, large tunnelling species belonging to the Geotrupidae were not collected in this study. Geotrupidae may be abundant and high functionally relevant in terms of removing dung on European mountains (Jay-Robert et al., 2003; Chamberlain et al., 2015) but are rare in Anatolia (Anlaş, 2011). The lack of large species of Geotrupidae contrasts with the stability or even increase in the relevance of large species of Scarabaeinae paracoprids at the highest localities, mainly in pasturelands and during late-spring and summer.

The open/closed structure of the habitat only partially influences dung beetle assemblages independently of altitude or season. Open habitats are slightly richer in species than closed or mixed habitats, mainly in lowlands. These results partially contradict the results of other studies carried out under Mediterranean conditions (Lumaret \& Kirk, 1987; Zamora et al., 2007; Numa et al., 2012; Errouissi \& Jay Robert, 2019), in which only a few species show preferences for either forest or scrubland, probably because of biogeographical and/or historical factors (Cambefort \& Walter, 1991; Martín-Piera \& Lobo, 1996). The generally few species in the closed biomes in the Palaearctic region contrast with the high diversity of dung beetles in tropical forests (Radtke et al., 2010). The preference of dung beetles for open habitats in the Palaearctic is thought to be linked with the arrival of faunal elements from Asia during the Oligocene-Miocene in parallel with the expansion of grasslands and the diversification of ruminant Artiodactyla that produce soft fibrous droppings (Sole \& Scholtz, 2010; Strömberg, 2011). Nevertheless, there was a similar 
abundance and biomass of dung beetles in both open and closed habitats in our study and only mixed habitats (forest-pasture ecotones) seemed to harbour fewer individuals and less biomass (mainly corresponding to the lack of species of Scarabaeinae). Nor was there a notable decline with altitude in the abundance and biomass in closed habitats, indicating that the species inhabiting forest localities can have large populations (such as Melinopterus prodromus, Nimbus johnsoni, N. obliteratus, Onthophagus ovatus and O. similis) and large body size (as in the case of Copris lunaris, Onthophagus gibbulus and Scarabaeus pius). The influence of the quantity of dung available in Mediterranean forests is an important factor in determining the abundance and biomass of dung beetles when a regular supply of dung is available (Kadiri et al., 1997). It is likely that the comparatively high diversity of forest dung beetle assemblages in this region could be due to the presence of an abundance of wild mammals, which may partially counteract the assumed filtering effect of the structure of the vegetation.

These results also indicate that the forests are not refuges when the environmental conditions are harsh, both seasonally and spatially. Again, this contrasts with the interaction between vegetation and altitude recorded in the northern Iberian Peninsula, which specifically include species of Aphodiinae (Menéndez \& Gutiérrez, 1996). In this study, some species occur in lowland forest habitats, which also inhabit pastures at higher altitudes. More detailed studies are needed to determine whether the habitat preferences of the different populations of the same species of dung beetle depend on the altitude, since this may indicate that climate has a greater effect on controlling population size than the vegetation, which is not directly linked with climate (luminosity, soils characteristics, availability of other supplementary trophic resources, etc.).

The seasonal pattern recorded at the different localities generally follows the classical Mediterranean bimodal pattern (Lumaret \& Kirk, 1991) associated with summer drought, with the highest species richness and abundance values recorded in the most climatically favourable seasons (spring and autumn). This bimodal seasonal pattern is especially evident for the endocoprid Aphodiinae species, blurred in the case of small species of Scarabaeinae and unimodal for the large species of Scarabaeinae, which are not active in the coldest months. This may be due to the dweller species of Aphodiinae being adversely affected by summer droughts. Scarabaeinae are generally adapted to warm conditions and inhabit relatively arid and tropical areas (Davis \& Scholtz, 2001), whereas most Aphodiinae prefer temperate to temperate-cold conditions, probably because of their biogeographic origin (Cabrero-Sañudo \& Lobo, 2009). Thus, the interplay between local climatic conditions (mainly temperature) and evolutionary conserved preferences of species (Wiens \& Graham, 2005; Merckx et al., 2015) seem to explain current seasonal and altitudinal gradients, as well as contributing to an understanding of the relative occurrence of Aphodiinae and Scarabaeinae (Lobo, 1997). However, the general bimodal pattern was not only recorded when the seasonal responses of the different groups were analysed separately, but also when the specific seasonal pattern at each locality was examined as is recorded in other studies (Jay-Robert et al., 2008; Foord \& Dippenaar-Schoeman, 2016). This indicates that these altitudinal patterns are deeply affected by the interplay between the climatic factors influencing all insect development stages and the thermal and hydric preferences of species. These results may also indicate that the most stressful periods impose a severe environmental constraint on those species unable to maintain viable populations throughout the entire year at a site because the favourable period shortens with increasing altitude. Cold temperatures and frosts during winter at high altitudes would only allow a few species to complete their life cycles there because all developmental stages are exposed to these harsh conditions (Mani, 1968; Chown \& Nicolson, 2004). The low number of species able to populate high altitude sites under an a priori favourable climatic conditions, such as summer for ectotherm species, may be explained by the fact that these species also need to cope with the severe winter conditions during some of their developmental stages (Mani, 1968). Ultimately, the physiological mechanisms protecting insects from cold (at high altitudes) and desiccation (at low altitudes) seem to be interrelated (Sinclair et al., 2013). Thus, an autumnal peak was not recorded at the highest altitude and the spring peak was particularly noticeable in lowland and in mid-mountain localities (around 1200 $\mathrm{m})$, altitudes above which species richness, abundance and biomass declined considerably. Highland and lowland sites differ in their seasonal patterns due to the restrictions imposed by the harsh winter conditions experienced at high altitudes. Similarly, the seasonal bimodal pattern becomes unimodal, peaking in late-spring/summer when only large species of Scarabaeinae were considered (rolling and tunnelling spp.). These large species seem to be able to survive during the hottest months of the year at all altitudes and habitats probably because of their capacity of thermal regulation (Verdú et al., 2006). The bimodal pattern was blurred in lowland pastures when abundance or biomass are considered (Fig. 5). This was due to the relevance of the large species of Scarabaeidae (such as Sisyphus schaefferi, Copris lunaris, Gymnopleurus geoffroyi, G. mopsus and Scarabaeus pius) and an abundance of small species of Scarabaeinae (such as Onthophagus ruficapillus, O. carpanetoi, O. furcatus, Euoniticellus fulvus, Caccobius schreberi, $C$. histeroides) or even some species of Aphodiinae (such as Colobopterus erraticus and Bodilus lugens).

In conclusion, this study corroborates thermal energy as fundamental to explaining altitudinal patterns in dung beetle assemblages and changes in altitudinal gradients during the course of a year. Our results, however, also confirm that different evolutionary lineages have distinct altitudinal patterns, which indicates that the effect of climate depends on evolutionarily conserved eco-physiological constraints. Both of these factors interact so that contemporary climatic scenarios act as filters, with the "actors" (species) being selected according to their pre-adapted preferences. 
Our results also indicate that in the eastern Mediterranean mountain chain studied the altitudinal pattern recorded is intermediate between that recorded in southwest Mediterranean mountain chains located on the Iberian Peninsula and other northern mountains chains recognized as Pleistocene refuges for dung beetles. In spite of the low number of narrowly distributed species recorded in our study there was a mixture of species with different biogeographic origins and eco-physiological preferences recorded on the mountain studied. Thus, the change in the composition of the dung beetle assemblages partially attenuates the decrease in species richness with altitude, although it should be emphasized that the lack of species of Geotrupidae species and high mountain endemics indicate that this region was not colonized by many cold adapted lineages.

ACKNOWLEDGEMENTS. This study was funded by project (2011-8) of the Kütahya Dumlupinar University Scientific Research Unit.

\section{REFERENCES}

AKMAN Y. 1995: Türkiye orman vejetasyonu. [Forest Vegetation of Turkey.] Ankara Üniversitesi Fen Fakültesi, Ankara, 448 pp. [in Turkish].

AKMAN Y. 1999: İklim ve Biyoiklim (Biyoiklim metodlarl ve Türkiye iklimleri). [Climate and Bioclimate (Bioclimatic Methods and Turkey Climate).] Kariyer Matbaacılık, Ankara, 350 pp. [in Turkish].

ANLAȘ S. 2011: Studies on the dung-inhabiting beetles (Insecta: Coleoptera) community of Western Anatolia, Turkey. - Ecol. Balkan. 3: 9-14.

Baraud J. 1977: Coléoptères Scarabaeoidea: Faune de l'Europe occidentale: Belgique, France, Grande-Bretagne, Italie, Péninsule ibérique. Supplément à la Nouvelle Revue d'Entomologie, Vol. 7., Toulouse, 352 pp.

Beck J., McCain C.M., Axmacher J.C., Ashton L.A., Bärtschi F. Brehm G., Chol S.-W., Cizek O., Colwell R.K. \& Fiedler K. 2017: Elevational species richness gradients in a hyperdiverse insect taxon: a global meta-study on geometrid moths. - Global Ecol. Biogeogr. 26: 412-424.

Birkett A.J., Blackburn G.A. \& Menéndez R. 2018: Linking species thermal tolerance to elevational range shifts in upland dung beetles. - Ecography 41: 1510-1519.

Brown J.H., Gillooly J.F., Allen A.P., Savage V.M. \& West G.B. 2004: Toward a metabolic theory of ecology. - Ecology $\mathbf{8 5}$ 1771-1789.

CABrero-SAÑudo F.J. \& Lobo J.M. 2009: Biogeography of Aphodiinae dung beetles based on the regional composition and distribution patterns of genera. - J. Biogeogr. 36: 1474-1492.

CAMBefort Y. \& Walter P. 1991: Dung beetles in tropical forests in Africa. In Hanski I. \& Cambefort Y. (eds): Dung Beetle Ecology. Princeton University Press, Princeton, NJ, pp. 198-210.

Chamberlain D., Tocco C., Longoni A., Mammola S., Palestrini C. \& RolANDO A. 2015: Nesting strategies affect altitudinal distribution and habitat use in Alpine dung beetle communities. - Ecol. Entomol. 40: 372-380.

Chown S.L. \& Nicolson S. 2004: Insect Physiological Ecology: Mechanisms and Patterns. Oxford University Press, Oxford, $243 \mathrm{pp}$.

Clarke K.R. \& Green R.H. 1988: Statistical design and analysis for a "biological effects" study. - Marine Ecol. Prog. Ser. 46: 213-226.
Clarke K.R. \& Gorley R.N. 2015: PRIMER v7: User Manual Tutorial. PRIMER-E, Plymouth, UK.

Colwell R.K. \& Lees D.C. 2000: The mid-domain effect: geometric constraints on the geography of species richness. Trends Ecol. Evol. 15: 70-76.

da Silva P.G., Lobo J.M., Carpintero Hensen M., Vaz-de-Mello F.Z. \& HeRNÁNDEZ M.I.M. 2018: Altitudinal gradient driving spatial and temporal $\beta$-diversity components: turnover and nestedness in subtropical dung beetle assemblages. - Divers. Distrib. 24: 1277-1290.

Davis P.H. 1965: Flora of Turkey and East Aegean Islands. Vol. 1-9. Edinburgh University Press, Edinburgh.

Davis A.L. \& Scholtz C.H. 2001: Historical vs. ecological factors influencing global patterns of scarabaeine dung beetle diversity. - Divers. Distrib. 7: 161-174.

Davis A.L., Scholtz C.H. \& Chown S.L. 1999: Species turnover, community boundaries and biogeographical composition of dung beetle assemblages across an altitudinal gradient in South Africa. - J. Biogeogr. 26: 1039-1055.

Errouissi F. \& JAY-RoberT P. 2019: Consequences of habitat change in euromediterranean landscapes on the composition and diversity of dung beetle assemblages (Coleoptera, Scarabaeoidea). - J. Insect Conserv. 23: 15-28.

Escobar F., Lobo J.M. \& HalfFter G. 2006: Assessing the origin of Neotropical mountain dung beetle assemblages (Scarabaeidae: Scarabaeinae): the comparative influence of vertical and horizontal colonization. - J. Biogeogr. 33: 1793-1803.

Espinoza V.R. \& NoRIEGA J.A. 2018: Diversity of the dung beetles (Coleoptera: Scarabaeinae) in an altitudinal gradient in the east slope of los Andes, Napo province, Ecuador. - Neotrop. Biodiver. 4: 144-150.

Foord S.H. \& DippenaAr-Schoeman A.S. 2016: The effect of elevation and time on mountain spider diversity: a view of two aspects in the Cederberg mountains of South Africa. - J. Biogeogr. 43: 2354-2365.

HANSKI I. 1980: The community of coprophagous beetles (Coleoptera, Scarabaeidae and Hydrophilidae) in northern Europe. - Ann. Entomol. Fenn. 46: 57-73.

HANSKI I. 1983: Distributional ecology and abundance of dung and carrion feeding beetles Scarabaeidae in tropical rain forests in Sarawak, Borneo. - Acta Zool. Fenn. 167: 1-45.

Hortal J., Diniz-Filho J.A.F., Bini L.M., Rodriguez M.A., BASelga A., Nogués-Bravo D., Rangel T.F., Hawkins B.A. \& Lово J.M. 2011: Ice age climate, evolutionary constraints and diversity patterns of European dung beetles. - Ecol. Lett. 14: 741-748.

Hsien T.C., Ma K.H. \& Chao A. 2016: iNEXT: an R package for rarefaction and extrapolation of species diversity (Hill numbers). — Meth. Ecol. Evol. 7: 1451-1456.

JAY-RoBert P., LoBo J.M. \& LuMARET J.-P. 1997: Altitudinal turnover and species richness variation in European montane dung beetle assemblages. - Arctic Alpine Res. 29: 196-205.

JaY-Robert P., Lumaret J.-P., Lobo J.M. \& André J. 2003: The relationship between body size and population abundance in summer dung beetle communities of South-European mountains (Coleoptera: Scarabaeoidea). - Rev. Ecol. / Terre Vie 58: 307-320.

JAY-Robert P., Lumaret J.-P. \& Lebreton J.D. 2008: Spatial and temporal variation of mountain dung beetle assemblages and their relationships with environmental factors (Aphodiinae: Geotrupinae: Scarabaeinae). - Ann. Entomol. Soc. Am. 101: 58-69.

Kadiri N., Lobo J.M. \& Lumaret J.-P. 1997: Conséquences de l'interaction entre préférences pour l'habitat et quantité de ressources trophiques sur les communautés d'insectes copro- 
phages (Coleoptera: Scarabaeoidea). — Acta Oecol. 18: 107 119.

Laiolo P., Pato J. \& Obeso J.R. 2018: Ecological and evolutionary drivers of the elevational gradient of diversity. - Ecol. Lett. 21: 1022-1032.

LegendRe P. \& Gallagher E.D. 2001: Ecologically meaningful transformations for ordination of species data. - Oecologia 129: $271-280$.

Lово J.M. 1993: Estimation of dung beetle biomass (Coleoptera: Scarabaeoidea). - Eur. J. Entomol. 90: 235-238.

Lово J.M. 1997: Influencias geográficas, históricas y filogenéticas sobre la diversidad de las comunidades locales: una revisión y algunos ejemplos utilizando Scarabaeoidea coprófagos (Coleoptera, Laparosticti). — Bol. Asoc. Esp. Entomol. 21: $15-31$.

Lово J.M. 2000: Species diversity and composition of dung beetle (Coleoptera: Scarabaeoidea) assemblages in North America. - Can. Entomol. 132: 307-321.

Lobo J.M. \& Halffter G. 2000: Biogeographical and ecological factors affecting the altitudinal variation of mountainous communities of coprophagous beetles (Coleoptera: Scarabaeoidea): a comparative study. - Ann. Entomol. Soc. Am. 93: 115-126.

Lobo J.M., Chehlarov E. \& Guéorguiev B. 2007a: Dung beetle assemblage variation with altitude in the Bulgarian Rhodopes Mountains: a comparison. - Eur. J. Entomol. 104: 489-495.

Lobo J.M., GuÉorguiev B. \& Chehlarov E. 2007b: Convergences and divergences between two European mountain dung beetle assemblages (Coleoptera, Scarabaeoidea). - Anim. Biodiv. Conserv. 30: 83-96.

Lomolino M.V. 2001: Elevation gradients of species-density: historical and prospective views. - Global Ecol. Biogeogr. 10: $3-13$.

LuMARET J.-P. \& KiRK A. 1987: Ecology of dung beetles in the French Mediterranean region (Coleoptera: Scarabaeidae). Acta Zool. Mex. 24: 1-55.

Lumaret J.-P. \& KirK A. 1991: South temperate dung beetles. In Hanski I. \& Cambefort Y. (eds): Dung Beetle Ecology. Princeton University Press, Princeton, NJ, pp. 97-115.

Lumaret J.-P. \& Stiernet N. 1991: Montane dung beetles. In Hanski I. \& Cambefort Y. (eds): Dung Beetle Ecology. Princeton University Press, Princeton, NJ, pp. 242-254.

Lumaret J.-P. \& Stiernet N. 1992: Biogeography of dung beetle communities in the Western and Central Alps (Coleoptera, Scarabaeoidea). - Biogeografia 16: 425-436.

Lumaret J.-P. \& STIERnet N. 1994: Adaptation and evolutive strategies of dung beetles in high mountains (Coleoptera, Scarabaeoidea). - Ecologie 25: 79-86.

MANI M.S. 1968: Ecology and Biogeography of High Altitude Insects. Series Entomologica Vol. 4. Dr. V. Jung, The Hague, $528 \mathrm{pp}$.

Martín-Piera F. \& Lobo J.M. 1996: A comparative discussion of trophic preferences in dung beetle communities. - Anim. Biodiv. Conserv. 19: 13-31.

Martín-Piera F., Veiga C.M. \& Lobo J.M. 1992: Ecology and biogeography of dung-beetle communities (Coleoptera, Scarabaeoidea) in an Iberian mountain range. - J. Biogeogr. 19: 677-691.

McCoy E.D. 1990: The distribution of insects along elevational gradients. - Oikos 58: 313-322.

MENÉNDEZ R. \& GuTIÉRREZ D. 1996: Altitudinal effects on habitat selection of dung beetles (Scarabaeoidea Aphodiidae) in the northern Iberian peninsula. - Ecography 19: 313-317.

Menéndez R., GonzÁlez-Megías A., JaY-Robert P. \& MarquézFERRANDO R. 2014: Climate change and elevational range shifts of dung beetles. - Global Ecol. Biogeogr. 23: 646-657.
Merckx V.S., Hendriks K.P., Beentjes K.K., Mennes C.B., Becking L.E., Peijnenburg K.T., Afendy A., Arumugam N., De Boer H. \& BiUn A. 2015: Evolution of endemism on a young tropical mountain. - Nature 524: 347-350.

Mongyeh E.T., Philips T.K., Kimbi H.K. \& FoKam E.B. 2018: Elevational and possible bushmeat exploitation effects on dung beetle (Scarabaeidae: Scarabaeinae) communities on Mount Cameroon, West Central Africa. - Environ. Entomol. 47: 1072-1082.

Monteith G.B. 1985: Altitudinal transect studies at Cape Tribulation, North Queensland VII. Coleoptera and Hemiptera (Insecta). - Queensl. Nat. 26: 70-80.

Numa C., Lobo J.M. \& Verdú J.R. 2012: Scaling local abundance determinants in Mediterranean dung beetles. - Insect Conserv. Diver. 5: 106-117.

Nunes C.A., Braga R.F., Figueira J.E.C., de Siqueira Neves F. \& FERNANDES G.W. 2016: Dung beetles along a tropical altitudinal gradient: environmental filtering on taxonomic and functional diversity. — PLoS ONE 11: e0157442, 16 pp.

OOMmen M.A. \& SHANKER K. 2005: Elevational species richness patterns emerge from multiple local mechanisms in Himalayan woody plants. - Ecology 86: 3039-3047.

RadtKe M.G., Da Fonseca C.R.V. \& Williamson G.B. 2010: Dung beetle communities: a Neotropical-North Temperate comparison. - Neotrop. Entomol. 39: 19-27.

RICKLEFS R.E. 2006: Evolutionary diversification and the origin of the diversity-environment relationship. - Ecology 87: S3S13.

Romero-Alcaraz E. \& Ávila J.M. 2000: Effect of elevation and type of habitat on the abundance and diversity of Scarabaeoid dung beetle (Scarabaeoidea) assemblages in a Mediterranean area from Southern Iberian Peninsula. - Zool. Stud. 39: 351-359.

Rosenzweig M.L. 1995: Species Diversity in Space and Time. Cambridge University Press, New York, 436 pp.

Sinclair B.J., Ferguson L.V., Salehipour-Shirazi G. \& MacMilLAN H.A. 2013: Cross-tolerance and cross-talk in the cold: relating low temperatures to desiccation and immune stress in insects. - Integr. Comp. Biol. 53: 545-556.

Sole C.L. \& Scholtz C.H. 2010: Did dung beetles arise in Africa? A phylogenetic hypothesis based on five gene regions. Mol. Phylogenet. Evol. 56: 631-641.

STRÖMBERG C.A. 2011: Evolution of grasses and grassland ecosystems. - Annu. Rev. Earth Planet. Sci. 39: 517-544.

SZEWCZYK T. \& MCCAIN C.M. 2016: A systematic review of global drivers of ant elevational diversity. - PLOS ONE 11: e0155404, $16 \mathrm{pp}$

Veiga C.M., Lobo J.M. \& Martín-Piera F. 1989: Las trampas pitfall con cebo, sus posibilidades en el estudio de las comunidades coprófagas de Scarabaeoidea (Col.). II. Análisis de efectividad. - Rev. Ecol. Biol. Sol 26: 91-109.

Verdú J.R., Arellano L. \& Numa C. 2006: Thermoregulation in endothermic dung beetles (Coleoptera: Scarabaeidae): Effect of body size and ecophysiological constraints in flight. $-J$. Insect Physiol. 52: 854-860.

Wiens J.J. \& Graham C.H. 2005: Niche conservatism: integrating evolution, ecology, and conservation biology. - Annu. Rev. Ecol. Evol. Syst. 36: 519-539.

Zamora J., Verdú J.R. \& Galante E. 2007: Species richness in Mediterranean agroecosystems: spatial and temporal analysis for biodiversity conservation. - Biol. Conserv. 134: 113-121.

Received June 24, 2019; revised and accepted September 11, 2019 Published online October 11, 2019 
Supplementary file:

Table S1 (http://www.eje.cz/2019/034/S01.xlsx). Number of individuals of the collected dung beetle species in each site according to the three studied factors (Altitude, Habitat and Month).

The general body length and biomass of each species is provided according to literature (Baraud, 1977) and length-to-body weight relationships (Lobo, 1993). 